wiającego za objawionym charakterem pewnej idei religijnej, nieokreślonej jeszcze wyraźnie przez Kościól, i przyczynić się do jej dogmatyzacji czyli do powstania nowej formuly dogmatycznej względnie nowego dogmatu ściśle pojętego;

6o Z tego względu i w tym sensie można mówić też o ewentualne; zależności genetycznej dogmatu (ściśle pojętego) od liturgii.

Kraków

KS. EUGENIUSZ FIORKOWSIEI

\title{
WYOBRALENIA CHRUSTUSA
}

Należy z naciskiem zaznaczyć, że wbrew ogólnemu mniemaniu nie posiadamy wiernej podobizny Zbawiciela, ani opisu jego wyglądu, bo milczą o tym Ewangelie i najdawniejsi pisarze chrześcijańscy. Jak wylkazały badania, rzekomy list prokuratora Judei, Lentulusa, do senatu rzymskiego, jest przeróbką greckiego tekstu, pochodzącego dopiero $\mathrm{z}$ okresu wcześniejszego średniowiecza, a wszystkie podobizny oblicza, uważane za prawdziwe, są z pózniejszych czasów. Z tych najdawniejsza, którą rzekomo sam Chrystus miał posłać z listem Abgarowi, królowi Edessy, nie sięga poza VI wiek. W r. 944 przewieziono ją do Carogrodu. Po zdobyciu tego miasta w r. 1204, zagarnęli ją krzyżowcy, ale nie wiadomo gdzie się dziś znajduje, gdyż kilka kościołów Zachodniej Europy twierdzi, że jest $w$ jej posiadaniu. Na tej podstawie powstało opowiadanie o św. Weronice. W rzeczywistości imię to jest przemianą z "vera icon", czyli prawdziwe wyobrażenie, jals we wczesnym średniowieczu nazywano wspomniane rzekome podobizny Zbawiciela. Legenda o św. Weronice powstała z połączenia apokryficznych Aktów Piłata, czyli Ewangelii Nikodema, z V w., z opowiadaniem Euzebiusza (Hist. Eccles. VII, 18), że niewiasta uleczona $\mathrm{z}$ krwotoków, postawiła w Paneas w Palestynie pomnik Zbawicielowi. Ją też uważano za Weronikę. Legenda o odbiciu oblicza na chuście urobiła się we Francji. W bazylice Watykaŕskiej przechowana chusta, mocno zniszczona, zachowała tylko najogólniejsze zarysy twarzy. Ukazują ją jedynie w Wielki Tydzień i w szczególne uroczystości. W ciagu wieków wykonano $\mathrm{z}$ niej wiele podobizn, ale niedokładnych.

Nieraz pokazywano podobizny popiersia Chrystusa, z krótka brodą i długimi wlosami, uważane za prawdziwe i to: „według. portretu wyrytego na szmaragdzie na rozkaz cesarza Tyberiusza, byłej własności skarbca cesarskiego w Konstantynopolu, 
który dostał się w ręce Turków w r. 1453. Portret ten wraz z świętą włbcznia, która zraniła bok Pana Jezusa, ofiarowany został przez sułtana Bajazeta II papieżowi Innocentemu VIII, jalko wylkup za brata, który został wzięty do niewoli w Rodosie przez wojska chrześcijanskie".

Zgadza się, że gemma ta została przez sułtana Bajesida II ofiarowana papieżowi Innocentemu VIII razem z cząstką włóczni świę-

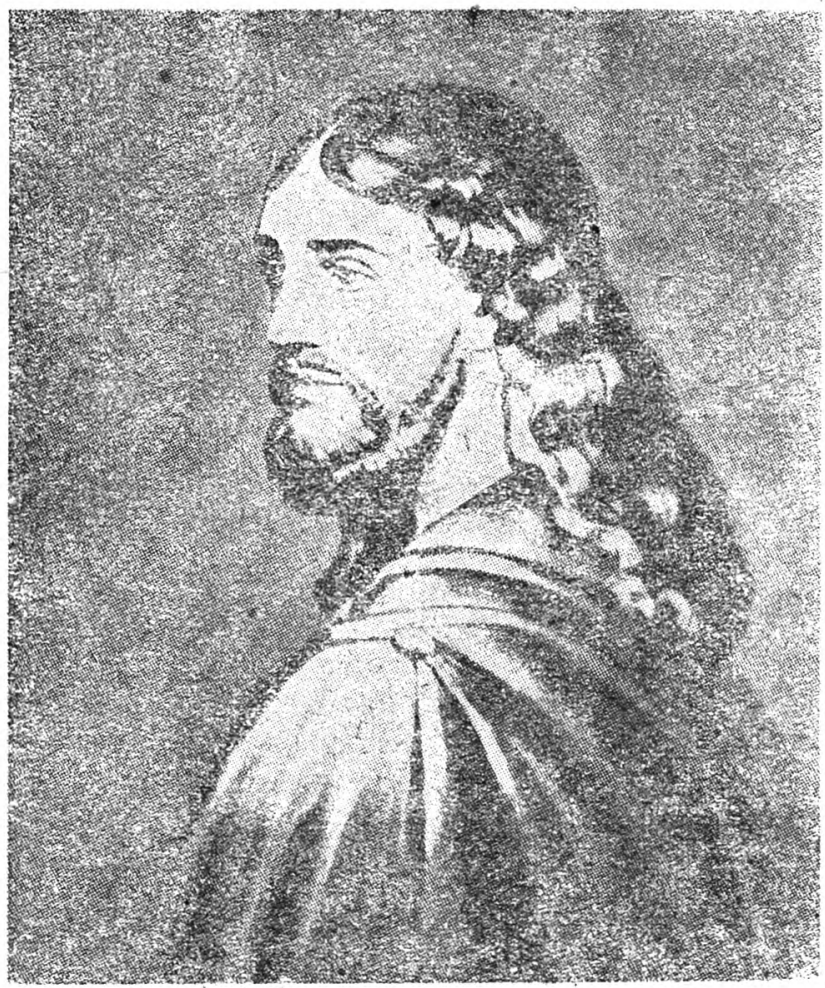

tej i ogromną sumą pieniędzy - za to, że papież zatrzymał w niewoli pretendenta do tronu sultańskiego Dżema. Twierdzenie jednak, że „to prawdziwy wizerunek Jezusa“ jest bezpodstawne. Eączenie gemmy z osobą cesarza Tyberiusza ma swoje źródło w apokryfach. Ponieważ Pan Jezus umarł za Tyberiusza, wciagnnięto jego imię w zmyślone legendy, zawarte w tzw. „Acta Pilati“", względnie w „Cura sanitatis Tiberii", pisma pochodzącego z VII wieku. Gemmy ryto $w$ sztuce bizantyńskiej do końca rozwoju tej sztuki, tj. do 
zajęcia Carogrodu przez krzyżowców w r. 1204, a ten szmaragd może tylko $z$ tego czasu $-z$ wieku XI lub XII pochodzić.

Około r. 1920 rozpowszechniano wiadomości o ,,autentycznych portretach Pana Jezusa i Apostołów" znajdujących się na srebrnym kielichu, który znaleziono w r. 1910 w Antiochii. W krótce jednak okazało się, że kielich ten jest falsyfikatem, sporządzonym w nowszych czasach.

Niektórzy pisarze z II do IV wieku, opierając się na proroctwach o wyniszczeniu Zbawiciela, sądzili, że byl on pozbawiony piękności, gdy inni byli wręcz odmiennego zdania; dowód najlepszy, że nie wiedziano wtedy, jak rzeczywiście Zbawiciel wyglądał. W każdym razie zgodnie $\mathrm{z}$ dążeniami sztuki grecko-rzymskiej co do sposobu wyobrażania bohatera, zależnie od podobizn Aleksandra Wielkiego, który nie nosir zarostu (przez wielu naśladowany), już przed czasami Konstantyna, pojawił się Chrystus piękny młodzieniec, o wyrazie szlachetnym i miłym. Jeżeli ta sama młodzieńcza postać ukazuje się w towarzystwie Adama i Ewy i dalszych osób ze Starego Zakonu, a następnie w Kanie Galilejskiej i przy innych cudach, to wyrażona jest $\mathrm{w}$ tym wiara w Bóstwo Chrystusowe. Młodzieńczy jest Dobry Pasterz na mozaikach z VI wieku, w mauzoleum Galli Placidii w Rawennie i tamże w kościele S. Apollinare Nuovo z tegoż czasu, na szeregu wyobrażeń cudów, a nawet w XIII wieku na bizantyńskich mozaikach u św. Marka w Wenecji, gdzie młody Zbawiciel błogosławi w stojącej postawie. Co najciekawsze, włoskie odrodzenie powróci do Zbawiciela bez zarostu, jak Michał Anioł na Sądzie Ostatecznym w Sykstyńskiej Kaplicy, Rafael na obrazie zmartwychwstałego-błogosławiącego w Galerii w Brescii, a Leonardo da Vinci na rysunku w Galerii Brera w Mediolanie, będącym studium do Wieczerzy Pańskiej. Leonarda naśladowali jego uczniowie, tworząc postacie młodzieńczego Zbawiciela, mianowicie Luini, Beltraffio i Timoteo Viti.

Ale wróćmy do dawnych czasów. Już od III wieku, jako znak dostojnego pochodzenia, włosy Zbawiciela stają się bujniejsze, a broda dłuższa, szaty lroju greckiego, dotąd niezbyt długie i niezbyt szerokie, przybierają na rozmiarach i falistości, jak u dostojników rzymskich, i takie juz pozostają do końca. Nie zaznaczano w niczym wschodniego pochodzenia. Od polowy IV wieku głowę otaczano nimbem, jednak nie zawsze i to nawet na wyobrażaniu cudów, gdzie należałoby zaznaczyć boskie pochodzenie, a krzyż na nimbie 
ustalił się dopiero w VI wieku. Młodzieniec pozostał w sztuce greckiej do czasów późniejszych pød nazwą Emanuela, ale już w IV w. pojawił się typ wschodni, $\mathrm{z}$ broda, jeszcze bez zaznaczenia rasy. Taki jest na mozaikach $w$ kościele św. Pudencjany w Rzymie i w absydzie laterańskiej bazyliki w popiersiu otoczonym obłokami, i na fresku w katakombach św. Piotra i Marcelina, wszystkich z okolo $400 \mathrm{r}$. Starano się w nich uwydatnić dostojeństwo, wiedze i potęgę. Aż do XII w. na Zachodzie pozostał Chrystus-młodzieniec,

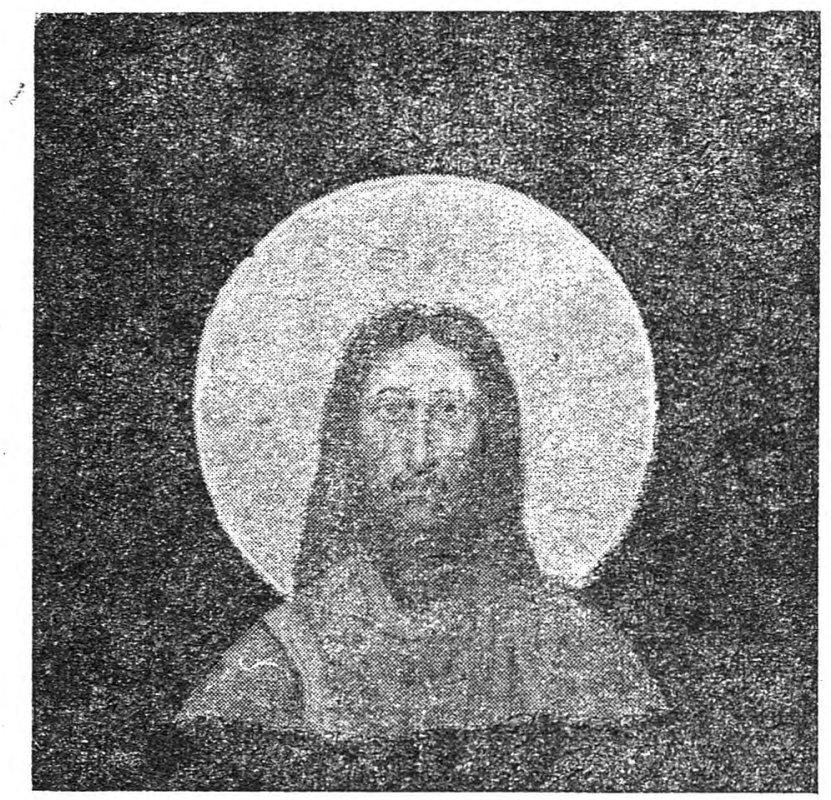

podkreślający czlowieczą jego naturę, gdy tamten raczej boska. Zwảaszcza $w$ kopulach i absydach bizantyńskich kościołów, a na tęczach rzymskich bazylik jak $u$ św. Pawła za murami Rzymu, ukazuje się we freskach i w mozaikach tak zw. Pantokrator, czyli groźny wiadca świata, zjawiający się na sąd ostateczny. Okres romański zachował poważnego brodatego Chrystusa, nawet z krzyża raczej królującego niż cierpiącego, a cierpieć zacząl dopiero pod wpływem średniowiecznej mistyki rranciszkańsko-dominikańskiej. Z posągów sławny jest gotycki błogesławiący w katedrze w Amiens, szlachetny, poważny i pogodny. Już od XIV w. włoska sztuka starała się, w przeciwieństwie do bizantyńskiej, więcej nadawać ludz- 
kiego wyrazu. Czasami ukazywał się Chrystus bez zarostu, jak na sławnym krzyżu królowej Jadwigi w katedrze na Wawelu, którego układ postaci i sztuczne włosy, wskazują na pochodzenie hiszpańskoneapolitańskie. Ponieważ światło pada $z$ góry, a głowa jest nachylona, więc $z$ dołu nie widać głẹboko-bolesnego wyrazu. Bez zastrzeżeń można stwierdzić, że najwspanialszym Ukrzyżowanym z okresu gotyku północnego jest znajdujący się w prawej nawie bocznej w Mariackim kościele w Krakowie, arcydzieło Wita Stwosza, gdzie mistrz wykazał niesłychaną wprawę $\mathrm{w}$ kuciu nawet kruchego pińczowskiego piaskowca tak, że przepaska na biodrach powiewa lekko, jak gdyby nie była kamienna. W niezrównany sposób wyrażona jest boleśe męlị w obliczu i w martwym natężeniu mieśni. Nie ustępuje mu Ukrzyżowany w tęczy tegoż kościoła, wyrzeźbiony w drzewie przez Stwosza na zamówienie mieszczki krakowskiej Doroty Szewcowej w r. 1473, ale znaczna odległość nie pozwala odpowiednio go oglądać, a tylko niedawno, kiedy w czasie odnawiania matejkowskiej polichromii ustawiono rusztowanie, można było ocenić tam cały artyzm stwoszowskiego geniuszu.

Najwięksi artyści włoskiego odrodzenia, jak Michał Anioł, Sodoma, Perugino, Correggio, Tintoretto itd. Wysilali się, by oddać głębię boleści w obliczu Zbawiciela na scenach z Męki Pańskiej, a Andrea Mantegna na obrazie w Galleria Brera, przedstawil nawet martwe jego zwłoki, w najtrudniejszym położeniu, bo od strony stóp, z głową w głębi, oddalając w ten sposób świetnie bezwładność martwoty.

Wielki Tizian wsławił się arcydziełem Grosz Czynszowy, w którym przeciwstawił świetlaną, spokojna postać Chrystusa, którego szlachetność przebija też w ruchu wytwornej dłoni, podstępnej, chytrej postaci faryzeusza, ukazujacego pieniądz zachłanną rẹką.

$Z$ poza Włochów wymienić należy Ukrzyżowanego Velazqueza w madryckiej Galerii Prado i rzeźbę Thorvaldsena »Przyjdźcie do mnie wszyscy ", jedną w Mariackim kościele w Kopenhadze, a drugą w katedrze na Wawelu, gdzie ten duński rzeźbiarz dorównał arcydzielom klasycznej sztuki.

W rytownictwie wsławił się Albrecht Dürer, wykonując dwa cykle, Wielkiej i Małej Pasji, peine wyrazistości i siły, znamienne dla okresu kończącego się gotyku północnego, a zaczynającego odrodzenia. Ciekawe to jest $\mathrm{w}$ drzeworycie Oblicza Chrystusa, z głebokim oddaniem boleści, że w oczach odbily się przegródki okienne, 


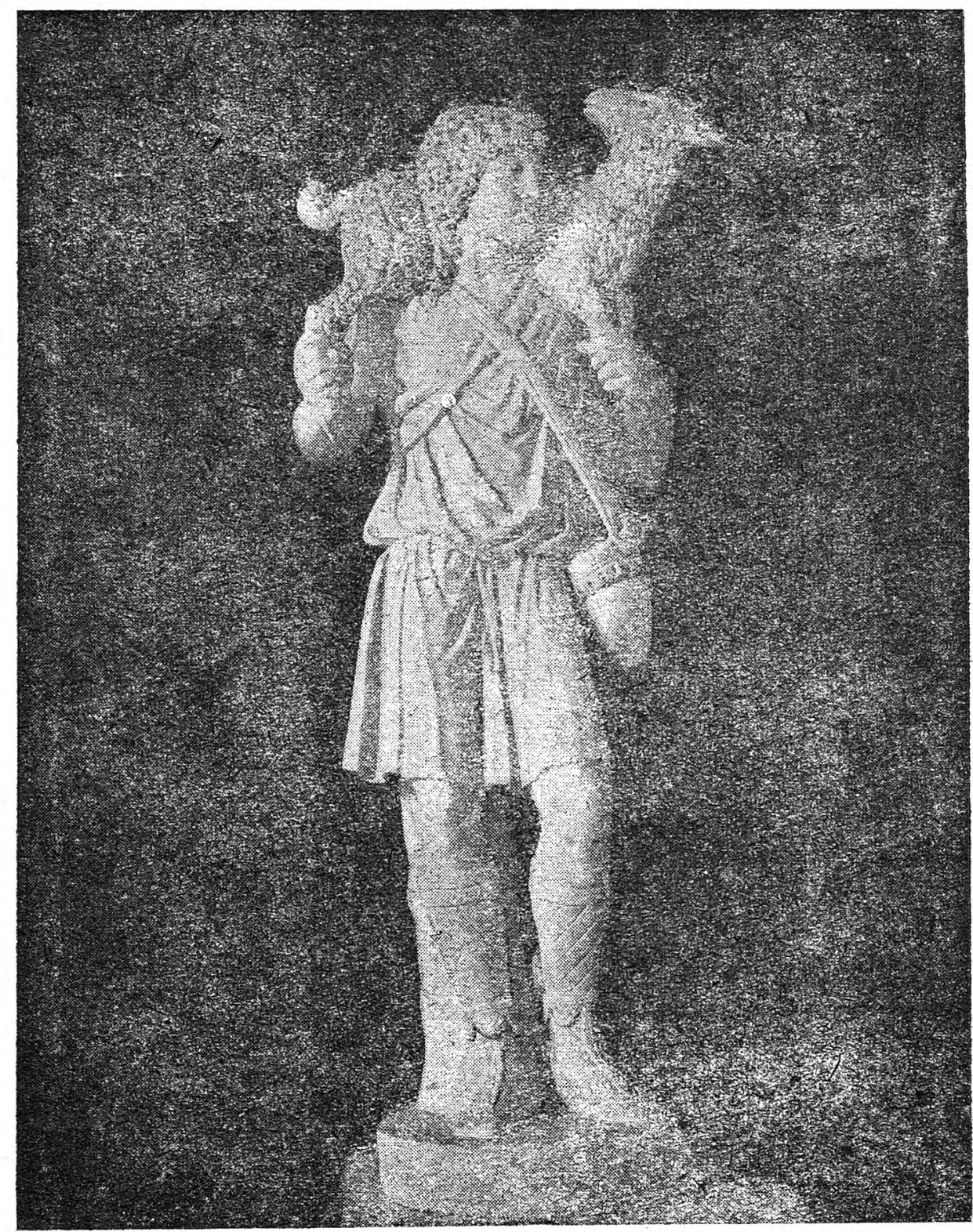


jak bywa w wypukîych lśniących przedmiotach, przy zamkniętych oknach. Widocznie więc Dürer narysował własne oblicze odbite w zwierciadle, dodając mu koronę cierniowa i nadając wyraz najgłębszej boleści.

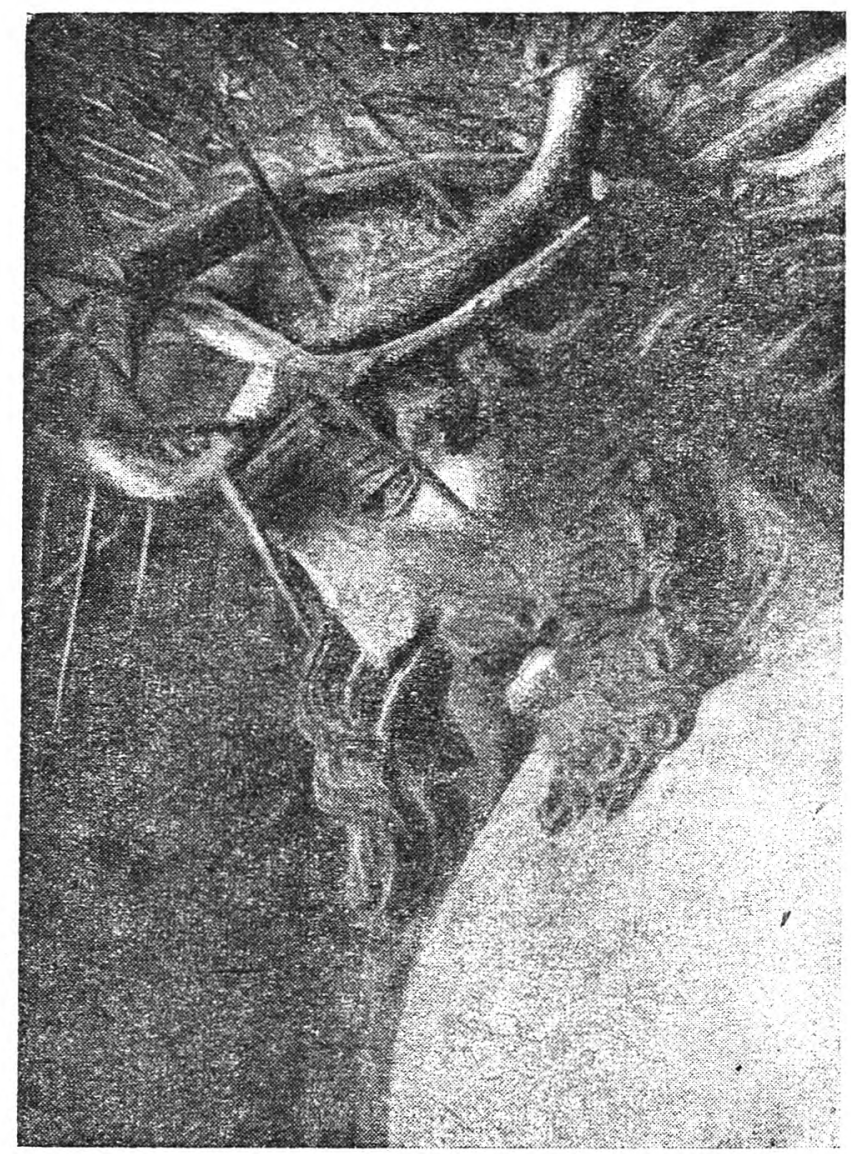

Ze symbolicznych wyobrazeń Zbawiciela w pierwszych wiekach występuje postaé Orfeusza, owego śpiewaka z Tracji, który śpiewem i gra na iutni uspokajal najdziksze zwierzęta, podobnie jak Chrystus łaska swą ujarzmia najtwardsze serca. Najczestszy był jednak Dobry Pasterz, wedle Ewangelii św. Jana (10, 1), Mateusza $(18,12)$ i jukasza $(15,3-7)$, niosący zgubioną owieczke na ramio- 
nach, albo strzegacy owiec. Z kilkunastu znanych posążków najstarszy i najpiçlmiejszy z początku III w. znajduje się w Muzeum na Lateranie, a z mozaik najokazalszá w grobowym kościółku Galli Placidii w Rawennie z V w., pasterz pasący owce pośród skał, przybrany w okazałe szaty, z krzyżem w ręce zamiast laski pasterskiej. $\mathrm{Na}$ obydwóch zabytkach jest on klasycznie pięirnym młodzieńcem.

Kraków

KS. TADEUSZ KRUSZYNS:KI

\section{SW. TOHASZ O LITURGII MSZY SW. \\ Weding Hementarza do IV Ksiegi Senteneji Piotra Lombara}

(Dokończenie)

\section{Ceremonie MISzy świß̨tej}

W "expositio textus" dystynkcji XII poświęca św. Tomasz m. in. obszerny wywód rozprowadzeniu słów Lombarda, że "w sakramencie dzieje sie przypomnienie tego, co (już) raz się stajo". Podejmując te mysll, pisze św. Tomasz, że kaplan przedstawia (repraesentat) Mękę Chrystusa nie tylko słowami lecz i czynnościami.

Wyliczając kolejno rodzaje poszczególnych czynności, wpierw i najobszerniej omawia znaki krzyża.

\section{Znaki krzyża}

Znak krzyża jest przypomnieniem blogosławieństwa Bociego i dlatego przystępując do referowania słów św. Tomasza omawiających znaki krzyża we Mszy św., warto tutaj wpierw zacytować jego sł̉owa zawarte nieco dalej w objaśnieniu dystynkcji XIII, że „blogosławieństwo Hostii nie jest w pierwszym rzędzie aktem kaplana, lecz samego Boga". Kontekst łączy tę myśl z samym aktem konsekracji. Lecz znaki krzyża czynione przez kapłana poza konsekracją są również $\dot{z y w y m}$ obrazem i przypomnieniem tego akiu Bożego, stąd ich szczególnie silna wymowa i głę̨oka symbolika.

1. Po raz pierwszy na poczatku kanonu czyni kapłan trzy. znaki krzyża przy slowach: „...haec dona, haec munera, haec sancta sacrificia illibata..." dla zaznaczenia trzykrotnego oddania Chrystusa na krzyż: mianowicie przez Boga, przez Judasza i przez Źydów.

2. Trzy znaki czynione nad darami ofiarnymi przy słowach „benedictam, adscriptam, ratam..." oznaczają kapłanów, uczonych 